\title{
NIẒĀM AL-MULK DAN KONTRIBUSINYA TERHADAP PEMIKIRAN POLITIK ISLAM
}

\author{
Ahmad Nur Fuad \\ Universitas Islam Negeri Sunan Ampel Surabaya, Indonesia \\ E-mail: nurfuad@uinsby.ac.id
}

\begin{abstract}
This article seeks to explore Nizām al-Mulk's political career and his contribution to Islamic political thought. As a prominent wazir of two Saljuq sultans, Alp Arslan and Malikshah, Niz̄ām al-Mulk played an important role in running the government for almost 30 years. His adherence to Sunni theological doctrines and Shafi'i school of law has made him a defender of Sunnism against other sects like Ismailism. As a political figure and thinker, Nizām al-Mulk regarded justice and religion as fundamental basis for state. In Siyäsat-nàma, he elaborates many political bodies needed to build a strong state and government, such as wazìr, qädì, tax collectors, military, and intelligent agency. It can be argued that Niz̄ām alMulk's political thought as formulated in his work, Siyasat-nama (the Book of Government), is based on his political and governmental experiences, his understanding of Islamic doctrines, and Persian political traditions.
\end{abstract}

Keywords: Niz̄ām al-Mulk; Siyāsat-nāma; political thought.

\section{Pendahuluan}

Nizāom al-Mulk merupakan fenomena menarik dalam sejarah politik Islam. Ia adalah figur politik yang hebat dan berpengaruh di dunia Islam pada abad ke-11. Kehebatannya terutama terletak pada fakta bahwa ia menjadi perdana menteri terkemuka selama hampir 30 tahun pada masa pemerintahan dua sultan Saljuk, yaitu Alp Arslan mulai 1063 sampai 1072, dan Malikshah mulai 1072 sampai 1092. Tidaklah berlebihan jika E.G. Browne menggambarkannya sebagai "most capable administrator, an acute statesman", ${ }^{1}$ sementara

${ }^{1}$ E.G. Browne, A Literary History of Persia, Vol. 2 (Cambridge: Cambridge University Press, 1964), 175. 
Philip K. Hitti menyebutnya sebagai "one of the ornaments of the political history of Islam". ${ }^{2}$ Kenegarawanan Nizām al-Mulk yang menonjol dapat dilihat dari karir politiknya yang panjang dan sekaligus risalahnya tentang politik yang berjudul Siyäsat-nāma. ${ }^{3}$

Artikel ini bertujuan untuk memberikan ilustrasi tentang karir politik Nizāām al-Mulk dan peranan penting yang ia mainkan dalam arena politik dan keagamaan pada abad ke-11. Artikel ini menelaah kontribusinya terhadap pemikiran politik Islam, menyangkut negara dan pemerintahan. Ia merumuskan gagasan-gagasan politiknya atas dasar pengalamannya sebagai Perdana Menteri dari dua sultan Saljuk. Watak dasar pemikirannya sesungguhnya berakar pada ajaran Islam dan tradisi politik Persia kuno. Dalam hal ini, Nizām al-Mulk menempati posisi khusus tidak hanya sebagai politisi atau negarawan, tetapi juga sebagai teoretisi politik. Risalahnya tentang pemerintahan, Siyäsat-näma, adalah karya satusatunya yang ditulis berdasarkan pengalaman praktisnya. Karena itu, karya ini dicirikan oleh praktikalitas dan aplikabilitas dari pemikirannya, dan merupakan refleksi dari pikiran cerdas penulisnya.

\section{Kehidupan Awal}

Nizāām al-Mulk memiliki nama asli Abū al-Hasan b. 'Alī b. Isḥāq al-Ṭūsī. Ia dilahirkan hari Jum'at, 21 Dhū al-Qa'dah 408 H, bertepatan dengan 10 April 1018 M di Radkan, sebuah desa dekat Ṭūs, kurang lebih lima puluh mil di sebelah utara kota Mashhad. ${ }^{4}$ Ayahnya, Abū al-Ḥasan 'Alī, adalah seorang pegawai pajak pada pemerintahan dinasti Ghaznawīyah di Khurasan. ${ }^{5}$ Sedangkan ibunya, Zamurad Khatun, meninggal dunia ketika Nizāam al-Mulk kecil mulai berhenti menyusu. Pada masa-masa itu, keluarganya menghadapi kesulitan ekonomi yang sangat parah. Meskipun

\footnotetext{
2 Phillip K. Hitti, History of the Arabs from the Earliest Times to the Present (London: Macmillan, 1967), 477.

3 S. Rizwan Ali Rizvi, "Nizām al-Mulk Tūsī: Not A Politician but A Statesman", Hamdard Islamicus, Vol. 3, No. 4 (1980), 81.

${ }^{4}$ S. Rizwan Ali Rizvi, Nizam al-Mulk. Tusi: His Contribution to Statecraft, Political Theory and the Art of Government (Lahore: SH Muhammad Ashraf, 1978), 1.

5 A.K.S. Lambton, "The Dilemma of Government in Islamic Persia: The Siyasat Nama of Nizam al-Mulk," Iran: Journal of the British Institute of Persian Studies, Vol. 22 (1984), 55.
} 
demikian, hal itu sama sekali tidak menghalangi jalannya pendidikan Nizāàm al-Mulk. ${ }^{6}$

Niẓām al-Mulk yang berasal dari keluarga dihqān (tuan tanah) ini sejak kecil telah terbiasa dengan lingkungan agamis. Bahkan, dalam usia 11 tahun ia telah mampu menghafal al-Qur'ān dengan sangat baik. Ia belajar pertama kali di bawah bimbingan seorang juris (ahli hukum) yang sangat terkenal, yaitu 'Abd al-Ṣamad. Kemudian, ia mendalami ilmu kalam (teologi) pada Muwaffaq, seorang alim Shāfíī yang sangat masyhur di Nishapur. ${ }^{7}$ Karenanya, kesetiaannya kepada doktrin-doktrin Asy'ārīyah dalam teologi dan paham Shāfiłìah dalam hukum di kemudian hari dapat dijelaskan dari perspektif sosialisasi yang intensif dengan para ulama Sunnī itu.

Mengenai kegiatannya yang lain pada masa kecil, memang tidak banyak sumber yang mengungkapkannya secara detail. Yang jelas, ketika masyarakat sedang berada dalam keadaan tidak menentu dan terjadi disintegrasi pemerintahan pada tahun-tahun terakhir kekuasaan dinasti Ghaznawiyah, ${ }^{8}$ serta pada saat sebagian besar wilayah Khurasan telah jatuh ke tangan kaum Saljuk pada tahun 1040 M, Nizāam al-Mulk beserta ayahnya lari meninggalkan TTūs menuju Ghaznah, sampai pada akhirnya ia keluar dari pemerintahan Ghaznawiyah dan kemudian memasuki sitem pemerintahan Saljuk. ${ }^{9}$ Dari sinilah ia memulai karirnya dalam politik dan pemerintahan.

\section{Karir dan Prestasi Politik}

Mula-mula sekali Nizāam al-Mulk menduduki jabatan komandan di daerah Balkh yang sudah jatuh ke tangan Saljuk pada 1040. Kemampuannya melaksanakan tugas dengan baik dan berhasil tidaknya tidak terlepas dari proses interaksi yang intensif dengan ayahnya, dan pengalamannya yang didapatkan ketika

\footnotetext{
${ }^{6}$ Rizvi, Nizam al-Mulk Tusi.

${ }^{7}$ Ibid., 2. Ketika Nizām al-Mulk menjadi murid Muwaffaq di Nishapur, ia bersahabat dengan Omar Khayyām dan Hasan Ṣabāḥ. Yang pertama kemudian menjadi ahli matematika dan astronomi yang terkenal, sedaangkan yang kedua kelak menjadi pimpinan gerakan teroris yang membunuh Nizām al-Mulk pada 1092.

8 Lambton, “The Dilemma of Government", 55.

9 Harold Bowen, "Nizāam al-Mulk", The Encyclopaedia of Islam, New Edition, Vol. 8,69 .
} 
mengabdi pada pemerintahan Ghaznawīyah. Kesuksesan itulah yang mengantarkan dirinya ke jenjang kepemimpinan yang lebih tinggi. Pada 1053, ia ditarik ke pusat pemerintahan Chagri, dan kemudian menjabat letnan yang bertugas di wilayah Khurasan Timur.

Selama kurang lebih empat tahun, yaitu antara wafatnya Chagri (1059) dan wafatnya sultan Thogril-beg (1063), Nizāàm al-Mulk merupakan pejabat yang menguasai secara penuh semua wilayah Khurasan. Tentunya, selama masa itu ia banyak melakukan perubahan-perubahan dan pembauran dalam mengendalikan daerah itu dengan prestasi yang cukup gemilang, sehingga sultan Alp Arslan (pengganti Toghril) mengangkatnya sebagai wazir menggantikan pejabat sebelumnya, al-Kundurī yang bergelar 'Amīd al-Mulk. $^{10}$

Namun demikian, karir dan prestasi politik Nizām al-Mulk yang sangat mengagumkan ditunjukkan ketika ia menjabat wazir selama kurang lebih 30 tahun di masa sultan Alp Arslan dan Malikshah, dari 1063 sampai 1092 saat ia mati dibunuh. Selama tiga puluh tahun itu, ia merupakan figur sentral dan pusat pengendali seluruh urusan dan persoalan pemerintahan Saljuk, dan pada masa itu pulalah dinasti Saljuk mencapai puncak kejayaannya. Sebagai wazir sekaligus kepala Dewan Tertinggi (diwwän-i a lā, supreme divan), Nizām al-Mulk membawahi kantor-kantor dengan nama dan tugas sebagai berikut: (1) Diwwàn al-Inshä' wa al-Ṭghrä; yaitu kantor yang mengurusi masalah korespondensi ke dalam dan keluar, dan merencanakan serta merumuskan naskah perjanjian-perjanjian dengan para pemimpin negara lain; (2) Diwwàn al-Zimām wa al-Istifä; yaitu kantor yang mengurusi penghasilan negara dan pencatatan pajak negara; (3) Diwān Ishräf al-Mamälik; yaitu kantor yang menangani pemerikasaan keuangan negara; (4) Diwān al-'Ard, yaitu kantor yang mengurusi masalah ketentaraan dan kemiliteran dalam negara. $^{11}$

Pada setiap kantor (diwān) ditempatkan juru tulis (kätib, sekretaris) yang membantu pelaksanaan tugas-tugas administrasi

\footnotetext{
${ }^{10}$ Bowen, "Nizām al-Mulk".

${ }^{11}$ Lambton, "The Dilemma of Government"; Haroon Khan Sherwani, Studies in Muslim Political Thought and Administration, terj. M. Arief Lubis (Jakarta: Tintamas, 1964), 129-130.
} 
masing-masing kantor. ${ }^{12}$ Pengelolaan negara, dengan demikian, telah dilakukan berdasarkan suatu sistem administrasi pemerintahan dan birokrasi yang relatif mapan dan teratur.

\section{Kebijakan Politik}

Dalam posisinya yang sangat sentral sebagai wažir itu, Niẓām al-Mulk berusaha mengorganisasi negara atas dasar kompromi antara kekuatan militer, administrasi sipil yang didukung oleh ulama Sunnī. Dalam pada itu, ia juga memiliki keinginan kuat untuk merestorasi institusi politik Iran masa lampau yang penuh dengan kestabilan, keadilan, dan kemakmuran. Sebagai seorang yang pernah terlatih dalam tradisi pemerintahan Ghaznawāyah, ia juga memfokuskan usaha-usaha dan langkah-langkahnya ke arah reorganisasi sosial-politik. Nampaknya, tujuan Nizāam al-Mulk yang paling utama adalah membangun kembali suatu struktur birokrasi dinasti Sasaniyah sebagaimana terwakili dalam sistem pemerintahan Ghaznawiyah. ${ }^{13}$

Keinginan Nizām al-Mulk itu tampaknya didorong oleh kenyataan sejarah bahwa "untuk berjalannya suatu imperium (negara, kerajaan), Arabisme murni itu sendiri terasa masih kurang sempurna bagi konsep-konsep politik". ${ }^{14}$ Dengan adanya kekuatan pengaruh 'Abbāsīyah-Persia, perkembangan demi perkembangan tumbuh pesat, khususnya sejak pusat pemerintahan dipindahkan ke Irak, yang berarti bahwa khalifah-khalifah 'Abbāsīyah harus mempekerjakan beberapa orang yang telah mewarisi tradisi pemerintahan Persia sebagai pejabat-pejabat penting. ${ }^{15}$ Jabatan wazir yang ada pada masa-masa awal pemerintahan 'Abbāsīyah dan berlanjut sampai masa dinasti Saljuk dianggap sebagai hasil pengambilan tradisi orang-orang Persia. Mereka itulah yang benarbenar berkuasa penuh atas jalannya pemerintahan jika khalifah sangat lemah dan tidak memiliki kecakapan dan kesanggupan untuk memerintah.

\footnotetext{
${ }^{12}$ Kajian lebih mendalam mengenai sistem administrasi pemerintahan pada masa Saljuk dapat dilihat dalam Aḥmad Kamāl al-Dīn Hilmī, al-Saläjiqah fì al-Tärikh wa al-Hadàrah (Kuwait: Dār al-Buhūth al-'Ilmīyah, t.th.), 208-214.

${ }^{13}$ Marshal G.S. Hodgson, The Venture of Islam II (Chicago: The University of Chicago Press, 1974), 44.

${ }^{14}$ W. Montgomery Watt, Pemikiran Teologi dan Filsafat Islam, terj. Umar Basalim (Jakarta: P3M, 1987), 94.

${ }^{15}$ Ibid., 95.
} 
Untuk mencapai dan mewujudkan maksud yang pertama, yaitu reorganisasi sosial-politik, Niẓām al-Mulk membentuk suatu korp administratur yang loyal dan setia kepadanya dan kepada doktrindoktrin keagamaan Sunnī. Untuk keperluan itu, ia kemudian mendirikan sebuah lembaga sebagai tempat mendirikan caloncalon birokrat dan administatur. Selain memberikan bekal keterampilan dan kecakapan teknis, lembaga tersebut terutama sekali menekankan pengajaran pengetahuan keagamaan dan pandangan tradisional. Sunnisme telah menjadi pandangan ideologis semua kalangan dari murid, profesor, dan penguasa politik saat itu, sekaligus sebagai alat justifikasi (pembenaran) bagi praktik dan kebijakan politik. ${ }^{16}$

Selama masa sultan Alp Arslan, Nizāam al-Mulk selalu menyertai setiap lawatan dan kunjungan ke daerah-daerah yang hampir tiada henti-hentinya, meskipun ia tidak sempat ikut dalam pertempuran yang dikenal sebagai Battle of Manzikert. Selain itu, Nizām al-Mulk juga sering memimpin operasi militer, seperti pada peristiwa pertempuran di Istakhr tahun 1067. Ia merupakan otak pengatur (directing mind) seluruh urusan dan kebijakan politik.

Di antara kebijakan yang diambil dan dapat diterapkan serta membawa pengaruh bagi kekuasaan adalah: ${ }^{17}$

1. Mempekerjakan sejumlah besar orang-orang Turki yang sudah berimigrasi ke Persia sebagai akibat dari kesuksesan Saljuk dalam setiap penyerangan ke luar wilayah där al-Isläm, dan juga ke wilayah dinasti Fāṭimīyah.

2. Menunjukkan bahwa kekuatan sultan sangat menarik dan ringan tangan, disertai pengampunan dan secara umum menerima kembali semua pemberontak yang mau tunduk dan menyerah.

3. Memelihara para penguasa lokal baik Sunnī maupun Shī‘ah dan menjadikan keluarga Saljuk sebagai gubernur di setiap propinsi.

4. Menyingkirkan perselisihan-perselisihan di sekitar suksesi (pergantian pemimpin) dengan penunjukan berdasarkan pengakuan umum terhadap Malikshah sebagai ahli waris (penerus), meskipun ia bukan anak tertua sultan.

\footnotetext{
${ }^{16}$ Hodgson, The Venture of Islam, 45; lihat juga R.W. Bulliet, "The PoliticalReligious History of Nishapur in The Eleventh Century", dalam D.H. Richards (ed.), Islamic Civilization 950-1150 (London: Cassirer, 1973), 85-86.

17 Bowen, "Nizāām al-Mulk", 70.
} 
5. Membangun dan menciptakan hubungan baik dengan khalifah al-Qā'im sebagai raja nominal (yaitu khalifah yang hanya diakui namanya saja tanpa kekuasaan politik).

Meskipun sultan Alp Arslan meninggal dunia, tetapi Niẓām alMulk masih tetap menduduki jabtannya sebagai wazì mendampingi sultan Malikshah yang masih sangat muda usia dan pengalamannya. Kerja sama kedua pemimpin itu berhasil mengangkat kembali kebesaran sejarah Islam baik dalam bidang politik, ilmu, dan kebudayaan. Oleh Malikshah, Nizām al-Mulk diberi gelar "Attabek" yang berarti Bapa Pangeran. Demikian pula, khalifah alQā’im menyebut waz̨ir itu dengan gelar "Qiwàm al-Din" (tiang agama) dan "Radì Amir al-Mu'minin".

Nizām al-Mulk, dalam periode Malikshah, menerapkan strategi atau kebijakan yang telah dirumuskan sebelumnya. Secara umum, ia bersama sultan Malikshah tetap berusaha menegakkan wibawa Saljuk di dunia Islam dan di kalangan non-Islam. Lebih dari itu, ekspansi (perluasan) wilayah terus dilakukan dengan mengarahkan penyerangan ke negeri Syiria, Mesir, dan berusaha merebutnya meski harus berhadapan dengan penguasa dinasti Fāṭimīyah. ${ }^{19}$ Wilayah taklukan ini kemudian diberikan kepada saudara Malikshah dan berdirilah Saljuk Syam di bawah pimpinan Tāj alDīn Tutush. Sedangkan wilayah Asia Kecil yang sudah lebih dahulu dikuasai diserahkan kepada Sulaymān b. Qutlumush dan berdirilah Saljuk Romawi. ${ }^{20}$

Semakin meluasnya wilayah kekuasaan dinasti Saljuk ternyata melahirkan persoalan baru di kalangan keluarga sultan. Perebutan wilayah kekuasaan antara Tāj al-Dīn dan Sulaymān tidak terhindarkan, dan berakhir dengan kematian Sulaymān. Tutush akhirnya merebut dan menguasai Halaba (Aleppo). Kondisi ini menjadi salah sati faktor disintegrasi kekuatan politik Saljuk secara keseluruhan. Meskipun demikian, tetap harus diakui bahwa wilayah yang dikuasai dinasti Saljuk terbentang dari Transoxiana di timur sampai sekitar Laut Tengah di sebelah barat yang meliputi daerahdaerah Iran, Syiria, Asia Kecil, dan Irak. Semuanya berada di bawah kontrol penguasa dinasti Saljuk.

\footnotetext{
18 Ibid.

${ }^{19}$ Hasan Aḥmad Maḥmūd dan Aḥmad Ibrāhīm al-Sharīf, al-'Alam al-Islām fì al'Ashr al-'Abbāsì (Kairo: Dār al-Fikr al-'Arabī, 1977), 598-599.

${ }^{20}$ Ibid.
} 
Berkat langkah-langkah Nizām al-Mulk, Saljuk dapat mempertahankan kembali Baghdad sebagai pusat keagamaan. Di Baghdad khalifah memiliki kekuasaan yang bersifat spiritual, setelah untuk beberapa tahun dipenjara dan tidak difungsikan sama sekali oleh orang-orang Shī‘ah. Sementara itu, kekuasaan politik berpusat di ibu kota Saljuk, Nishapur dan Rayy. Kedudukan khalifah di Baghdad yang dihormati dan diagungkan oleh sultan Saljuk itulah yang mampu mengembalikan wibawa yang pernah dimilikinya. ${ }^{21}$

Pada masa Nizām al-Mulk, tidak saja terjadi kebangkitan politik, tetapi juga berlangsung kebangkitan yang luar biasa dalam lapangan intelektualisme. ${ }^{22}$ Omar Khayyām adalah pelopor paling terkemuka dari perkembangan sains (ilmu-ilmu kealaman) dan kesusasteraan. Selain itu, pada masanya wilayah Persia dan Irak mencapai tingkat kemakmuran yang tinggi. ${ }^{23}$

Sebagai pemimpin (kepala) pemerintahan, Niẓām al-Mulk juga berhadapan dengan problem yang berkaitan dengan usaha membantu kehidupan sebagian besar tentara. Namun, ia mampu menyelesaikan masalah tersebut dengan memberikan bagian tanah pertanian kepada mereka (iqtā') ${ }^{24}$ Iq $t \bar{a}^{-}$adalah kebijakan pemberian tanah kepada tentara sebagai ganti dari gaji yang biasanya mereka terima pada masa-masa lampau. Kebijakan itu dimaksudkan oleh Nizām al-Mulk sebagai upaya memelihara dan menjaga agar pasukan tetap dalam kondisi yang kokoh dan kuat. Nizāām al-Mulk menyadari sepenuhnya bahwa Saljuk, sebagaimana dinasti lain, sangat tergantung kepada serdadu militer keturunan Turki yang sangat terkenal suka berpindah-pindah itu. Dengan jalan ini, tentara akan merasa terjamin kesejahteraannya dan mereka akan tetap menunjukkan kesetiaan (loyalitas) penuh kepada penguasa.

Kebesaran dinasti Saljuk yang diakui oleh pelbagai negara dan kerajaan pada waktu itu juga tidak terlepas dari keberhasilan Nizām al-Mulk menjalankan politik luar negeri atau diplomasi dengan banyak kepala negara lain dan juga dengan khalifah di Baghdad.

\footnotetext{
${ }^{21}$ Aḥmad Shalabī, Mawsū'at at-Tärīkh al-Islāmì wa al-Hādārah al-Islāmìyah (Kairo: Maktabah al-Nahḍah al-Mișrīyah, 1978), 431.

22 Ibid., 443.

${ }^{23}$ Karl Brockleman, Tārìkh al-Shu'üb al-Islämìyah (Beirut: Dār a-'Ilm, 1974), 274.

${ }^{24}$ Bowen, "Niz\}ām al-Mulk", 71.
} 
Termasuk dalam hal ini ialah tindakan-tindakan politiknya yang berhasil terhadap gerakan Ismā'îlīyah pimpinan Hasan Sabbāḥ. ${ }^{25}$

Integritas dan kebesaran Niẓām al-Mulk sebagai negarawan Muslim didukung oleh kemampuan berpikir yang tinggi dan intelektualitas yang tajam. Tidak belebihan jika ia dikategorikan sebagai pemikir (filsuf). Sebagai negarawan-pemikir, ia berpendapat bahwa seseorang tidak akan dapat memenuhi harapan dan mewujudkan tujuannya tanpa adanya suatu organisasi religio-sosiopolitik. ${ }^{26}$ Karena itu, fungsi negara dalam pandangannya ialah menjaga dan mewujudkan tidak saja kehidupan, kebebasan dan kemerdekaan melalui keadilan dan persamaan, tetapi juga kesejahteraan dan kebahagiaan bangsanya. Niz̄ām al-Mulk mencoba mentransformasikan ide tersebut ke dalam realitas politik, dan ia berhasil melakukannya dengan baik sekali, karena ia juga seorang pemikir-praktisi (a practical thinker).

\section{Refleksi Politik}

Pemikiran pokoknya yang tertuang dalam buku Siyāsat-nàma tidak akan dapat dipahami dengan baik kecuali jika nilai Islam ditempatkan sebagai kerangka acuan, karena Niẓām al-Mulk sangat dipengaruhi oleh universalisme Islam. Kenyataan ini berbeda dari pandangan orang-orang Barat yang menyatakan bahwa ia hanya mengabdi kepada Nasionalisme Persia. ${ }^{27}$ Jadi, ide dasarnya didasarkan kepada Islam, dan meskipun sebagai penguasa Muslim di negari timur ia telah mengambil beberapa institusi dan prosedur dari tradisi Iran pra-Islam, tetapi ini tidak berarti bahwa ia merupakan pengabdi Iranianisme. Institusi-institusi itu diambil hanya karena dipandang sesuai dengan kebutuhan negara Muslim kontemporer yang dipimpinnya.

Dari sini tampak bahwa pendidikan, sosialisasi, pengalaman dan bacaan Nizām al-Mulk yang banyak telah memberinya suatu latihan yang baik dalam kultur Islam dan tradisi akademis. Namun, perkembangan intelektualnya yang luar biasa itu sesungguhnya adalah karena kemampuan belajarnya secara langsung dari

\footnotetext{
${ }^{25}$ Rizvi, Nizamm al-Mulk Tusi, 163. Langkah-langkah diplomatik yang ditempuh Nizām al-Mulk untuk memantapkan posisi Saljuk di mata negara lain sangat bervariasi. Misalnya melalui perkawinan, pengiriman duta besar yang cerdik, dan sejumlah konsesi yang ditawarkan kepada musuh politik atau musuh Islam.

26 Ibid., 38.

27 Ibid., 41.
} 
pengalaman dan hubungannya yang bersifat personal dengan khalifah, sultan, dan ulama.

Meskipun demikian, kesuksesan demi kesuksesan itu tidaklah diperolehnya tanpa tantangan, terutama pada masa-masa puncak kejayaannya menjelang kematiannya pada 1092. Masalah suksesi di dalam dinasti Saljuk, menyangkut penentuan pengganti Malikshah, membawanya terlibat konflik tajam dengan istri sultan, Tarken Khatun, yang menginginkan anaknya, Ahmad, dijadikan sebagai putra mahkota. Sedangkan Nizāam al-Mulk sendiri mendukung Barkyaruk. Kontroversi yang juga melibatkan pejabat penting lainnya (para pendukung Tarken) inilah nampaknya menjadi salah satu faktor memburuknya hubungan Niẓām al-Mulk dengan sultan.

Nizām al-Mulk tampaknya memiliki prinsip yang tidak menyetujui campur-tangan (intervensi) kaum wanita dalam urusan politik dan pemerintahan. Ia berpandangan bahwa keterlibatan dan dominasi wanita dalam politik hanya akan menimbulkan kekacauan dan kerusuhan, sebab mereka banyak dipengaruhi oleh intrik-intrik dan sikap-sikap yang sama sekali tidak obyektif. ${ }^{28}$

Tantangan lain yang dihadapi adalah munculnya gerakan Ismāîlīyah yang menkonsolidasi kekuatan di dalam wilayah kekuasaan Saljuk. Kaum Ismāīilìah, sesuai dengan watak mereka, bertekad untuk merampas kekuasaan dalam rangka mendominasi dunia Muslim. Oleh karena itu, kegiatan mereka menyangkut segala usaha merongrong dan merusak organisasi politik Muslim termasuk kekhalifahan dan kesultanan, sekaligus menghancurkan doktrin-doktrin ortodoks. Niz̧ām al-Mulk sangat memahami gerakan ini dan mengingatkan sultan bahwa tidak ada musuh yang lebih berbahaya selain kaum Ismā̄ilinyah. Oleh sebab itu, kegiatankegaitan mereka yang cenderung subversif tidak bisa ditoleransi oleh negara, sehingga Niẓām al-Mulk menginginkan penggunaan kekerasan dalam menghadapi mereka, dan bahkan menyetujui kekerasan sebagai alat tindakan politik.

Dari sini, dapat diketahui bahwa terhadap prestasi yang diraih oleh Nizāam al-Mulk dan terhadap kemapanan Saljuk yang Sunnī itu dalam mempertahankan kekuasaan, muncul kecemburuan sosial dan politik yang pada akhirnya nanti menjadi penyebab kematian

${ }^{28}$ Lambton, “The Dilemma of Government”, 64. 
Niẓām al-Mulk. ${ }^{29}$ Adalah Ḥasan Ṣabbāḥ, kawan sekolah Niẓām alMulk di Nishapur, yang memiliki perasaan iri dan cemburu terhadap keberhasilan Nizāam al-Mulk. Ḥasan, yang beralih menjadi pengikut dan pemimpin Shī'ah itu, menuntut kepada Niz̧ām alMulk untuk memberinya jabatan tinggi dalam pemerintahan. Permintaan yang didasarkan pada kesepakatan mereka pada waktu masih sekolah itu tidak diterima oleh Nizām al-Mulk karena alasanalasan politik. ${ }^{30}$ Penolakan ini memperkuat motivasi Hasan untuk menciptakan kekacauan dan kerusuhan dengan melakukan pembunuhan terhadap lawan ideologi dan politiknya. Militansi dan komitmennya kepada ideologi Shī'ah mendorongnya mendirikan kelompok (partai) bawah tanah dengan mengambil markas di suatu tempat yang disebut Qil'at Alamūt. ${ }^{31}$

Kelompok Hasan ini sering mengancam keamanan dan ketertiban negara dengan aksi terorisme. Nizām al-Mulk sendiri juga menyusun langkah-langkah pemberantasan gerakan terorisme ini. Tapi, sebelum berhasil membasmi gerakan tersebut, Nizāam alMulk mati terbunuh oleh seorang aktivis Shī'ah yang diutus Hasan pada tahun $1092 .^{32}$

Memang terdapat beberapa dugaan menyangkut kematian ini, yang dikaitkan dengan memburuknya hubungan Nizāàm al-Mulk dengan istri sultan. Namun yang pasti, kejadian ini menjadi faktor melemahnya kekuatan politik Saljuk. Dengan mengutip buku The Story of Islam, Jousouf Sou'yb menyatakan: "This was one of the worst crimes of Ismaili fraternity, for Niẓām al-Mulk was a truly great son of Islam". ${ }^{33}$

\section{Pemikiran Politik Nizāam al-Mulk}

Sebagaimana disebutkan dalam bab-bab terdahulu, Niz̄ām alMulk tidak hanya seorang politikus ulung, tetapi juga pemimpin militer dan seorang cerdik pandai yang memiliki wawasan kebudayaan yang sangat luas. Niẓām al-Mulk sangat mencintai ulama dan selalu dekat dengan mereka. Tidak mengherankan jika Nizāàm al-Mulk memiliki gagasan mendirikan lembaga keagamaan,

\footnotetext{
${ }^{29}$ Rizvi, Nizam al-Mulk. Tusi, 16.

${ }^{30}$ Ibid., 17.

${ }^{31}$ Hilmī, al-Saläjiqah, 41.

32 Tàj al-Dīn al-Subkī, Tabaqat al-Shāfírȳah al-Kubrā (Kairo: al-Halabī, 1966), 323.

${ }^{33}$ Jousouf Sou'yb, Sejarah Daulat Abbasiyyah III (Jakarta: Bulan Bintang, 1978), 8.
} 
Madrasah Nizāmīyah dan mengarang sebuah buku yang di situ ia memformulasikan sutu metode administrasi pemerintahan negara. Buku itu diberi judul Siyäsat-nāma. ${ }^{34}$

Pada 1086, Malikshah sebagai sultan Saljuk memerintahkan beberapa pejabat di lingkungannya, seperti Nizāàm al-Mulk, Sharaf al-Mulk dan Majd al-Mulk, untuk mengemukakan pemikirannya tentang negara, makna kerajaan, apa-apa yang baik untuk dilaksanakan dalam konteks negara, pemerintahan, hukum dan agama serta tradisi-tradisi politik masa lampau yang relevan untuk membangun kerajaan Saljuk. Namun, Malikhsah akhirnya hanya menerima karya Niz̄ām al-Mulk yang berjudul Siyaasat-nàma, dan menjadikan buku itu sebagai pedoman. Sultan menganggap tulisan tersebut telah memenuhi keinginan dan kepentingannya. Ia menyatakan: "These chapters have been written exactly as I desired; there is notbing to add them; I will make this book my guide and follow its precepts". ${ }^{35}$

Pemikiran-pemikiran yang tekandung dalam buku itu merupakan refleksi yang sangat mendalam mengenai realitas sosialpolitik. Nizāam al-Mulk telah mampu mengartikulasikan gagasangagasan berdasarkan referensi etik yang bersumber dari ajaran Islam dan referensi kultural yang berkembang di dalam masyarakatnya. Ia mampu menerjemahkan prinsip-prinsip filosofis ke dalam kenyataan administratif, dan sebaliknya ia juga berhasil merumuskan realitas historis ke dalam suatu bangunan pemikiran yang menyeluruh.

Buku ini dinilai sangat penting tidak saja bagi penguasa masa lampau, tetapi juga untuk mereka yang sedang menjalankan roda pemerintahan dewasa ini. Sebab, dengan membaca dan memahami kandungan buku ini, penguasa akan semakin tercerahkan dalam urusan-urusan spiritual dan temporalnya; ia akan mampu mengapresiasi secara lebih baik kualitas kawan dan lawannya, ia akan mengetahui cara berperilaku yang benar, metode pemerintahan yang baik, aturan-aturan dalam mengelola istana, kantor, admisitrasi pajak, transaksi perdagangan dan dapat mengendalikan urusan rakyat dan tentara secara baik. ${ }^{36}$

\footnotetext{
${ }^{34}$ Shalabī, Mawsū'at al-Tārikh.

35 Nizām al-Mulk, The Book of Government, terj. Hubert Darke (London: Routledge and Kegan Paul, 1960), 2.

${ }^{36}$ Ibid.
} 
Meskipun demikian, Nizāam al-Mulk tidak bertujuan menciptakan sesuatu yang sama sekali baru (inovasi), melainkan hanya berusaha meningkatkan efektivitas kerja dan perilaku sultan dan pejabat penting lainnya untuk mencapai sasaran-sasaran politik dan tujuan negara itu sendiri.

\section{Agama dan Keadilan: Pandangan tentang Negara}

Negara merupakan suatu institusi politik yang menyandang atribut-atribut moral, sosial, dan kemanusiaan. ${ }^{37}$ Sebagai institusi, negara memiliki elemen-elemen yang menjadi indikasi keberadaan negara: penduduk, wilayah (teritorial), pemerintahan dan kedaulatan. Menurut Nizām al-Mulk, atribut moral negara itu melekat sebagai konsekuensi dari pengakuan atas kedaulatan Tuhan. Karena itu, selain harus mengabdi kepada kehendak Tuhan, negara juga bekewajiban melaksanakan perintah Tuhan sebagaimana diwujudkan dalam sharī'ah dan merefleksikan moralitas itu dalam kehidupan. $^{38}$

Agama Islam tidak menerangkan secara detail bentuk negara dan mekanisme dalam pemerintahannya. Ia hanya memberikan suatu kerangka dan landasan etik yang harus ditegakkan, seperti harus diwujudkannya keadilan dan persamaan dalam masyarakat, dilaksanakannya prinsip-prinsip musyawarah dan dihormatinya hak-hak manusia baik individual maupun sosial, yang dengan begitu setiap anggota masyarakat dapat mengaktualisasikan dirinya secara bebas dan merdeka. Nizām al-Mulk sangat menekankan pentingnya etika dan moralitas dalam kehidupan bernegara.

Dalam pandangan Nizām al-Mulk, negara memiliki dua dasar penting; agama yang benar dan keadilan. ${ }^{39}$ Posisi penting dari agama sebagai dasar negara dinyatakan oleh Niẓām al-Mulk sebagai berikut:

Hal paling penting yang dibutuhkan oleh seorang raja (penguasa) ialah keyakinan agama yang benar, karena negara dan agama laksana dua saudara; kalau terjadi gangguan dalam negara, agama juga akan mengalaminya; Kaum pembidah dan penjahat bermunculan; dan kalau agama mengalami kekacauan, maka muncullah kebingungan dalam negara; orang jahat mendapat kekuatan dan menjadikan raja runtuh; penyelewengan

${ }^{37}$ Rizvi, Nizam al-Mulk. Tusi, 95.

${ }^{38}$ Ibid.

${ }^{39}$ Lambton, "The Dilemma of Government", 56. 
berkembang secara meluas dan pemberontakan merasa bahwa mereka berkuasa. ${ }^{40}$

Negara, menurut Nizām al-Mulk, harus dituntun oleh sharī'ah, dan sistem politik Islam harus didasarkan pada agama. Negara berkewajiban menjaga dan melindungi komunitas Muslim dari segala bentuk gangguan dan melindungi mereka dari kemungkinan timbulnya perpecahan dan penyimpangan, serta harus menjalankan ketentuan-ketentuan yang terdapat dalam sharīah. Apabila agama hancur, maka entitas politik dan organisasi keagaman juga akan mengalami hal serupa.

Pandangan mengenai sangat pentingnya agama beserta nilainilainya dalam kehidupan bernegara juga dapat ditemukan dalam banyak karya pemikir Muslim sebelum Nizām al-Mulk, seperti alMawardī, Abū Ya'lā al-Farrā', dan lain-lainnya. ${ }^{41}$ Namun Nizām alMulk menekankan kesatuan agama dan politik, dan meyakini bahwa otoritas agama harus dihormati dan peranan shari'‘ah dalam negara harus dilindungi.

Sementara itu, keadilan, menurut Niz̄ām al-Mulk adalah sesuatu yang sama pentingnya dengan agama. Bahkan, ia juga menyatakan bahwa keadilan bisa jauh lebih penting dari agama, sebab negara akan dapat bertahan tanpa agama, tetapi tidak tanpa keadilan. Pandangan tersebut menunjukkan bahwa baik agama maupun keadilan itu merupakan dasar yang esensial bagi kelangsungan suatu negara.

Mengenai hubungan yang erat antara keadilan dan negara dinyatakan oleh Nizām al-Mulk sebagai berikut:

Adalah menjadi kewajiban raja untuk memperhatikan kebaikan Tuhan, dan kebaikannya itu terletak pada kemurahan yang diberikan kepada makhluk ciptaan-Nya, dan pada keadilan yang disebarkan di kalangan mereka. Negara yang didoakan oleh rakyatnya akan dapat bertahan dan berkembang sepanjang waktu, sedangkan rajanya akan menikmati kekuatan dan kemakmuran; di dunia ini ia akan memperoleh nama baik (kemasyhuran), dan di hari kemudian ia akan memperoleh keselamatan, dan akan mengalami kemudahan dalam penghitungannya. Dikatakan bahwa "negara akan dapat

40 Al-Mulk, The Book of Government, 63.

${ }^{41}$ Abū al-Hasan 'Alī b. Muhammad b. Habib al-Māwardī, al-Aḅkām al-Sulțānìah wa al-Wilāyàt al-Diñyah (Beirut: Dār al-Fikr, 1960); Abū Ya‘ lā b. al-Farrā', alAḅkām al-Sultānìyah (Beirut: Dār al-Fikr, 1994). 
bertahan meskipun tanpa agama, tetapi tidak dapat bertahan dengan adanya penindasan (ketidak-adilan). ${ }^{42}$

Berkaitan dengan penegakan keadilan di tengah-tengah kehidupan masyarakat, Nizāam al-Mulk menyatakan bahwa negara atau dalam hal ini penguasa, harus menindak para pelaku pemerasan dan penindasan. Jika seorang pejabat melakukan penindasan, maka dia harus dihukum dan diganti oleh orang lain yang lebih baik. ${ }^{43}$ Penguasa harus mengawasi secara intensif, memperbaiki dan mengingatkan mereka (pejabat) yang bertindak salah, memberikan keadilan dan mendengarkan aspirasi rakyat tanpa perantara, memberikan putusan kepada setiap orang sehingga tidak seorangpun berani melakukan tindak pemerasan dan ketidakadilan terhadap rakyat. ${ }^{44}$

Seperti telah disebutkan di muka, adalah menjadi tanggung jawab penguasa (sultan) untuk melindungi agama dan menegakkan keadilan demi keberlangsungan negara itu. Sebab, menurut Nizāam al-Mulk, sultan adalah orang yang ditunjuk dan diplilih oleh Tuhan untuk keperluan itu, dan bertanggung jawab kepada-Nya. Tidak ada perantara ataupun pemilihan oleh orang atau lembaga yang disebut abl al-hall wa al-'aqd. ${ }^{45}$

Nizāam al-Mulk menyatakan bahwa pada setiap kurun waktu, Tuhan memilih seorang manusia dan memberinya amanat untuk menjaga kebaikan dunia dan sekejahteraan hamba-Nya, untuk menutup pintu korupsi dan mencegah timbulnya kerusuhan dan kekacauan. ${ }^{46}$ Oleh sebab itu, Tuhan menganugerahkan sifat-sifat baik kepada orang itu.

Dengan membawa Tuhan ke dalam negara, baik sebagai penunjuk sultan maupun sebagai peletak dasar-dasar hukum (sharī'ah), tidak berarti bahwa Nizāàm al-Mulk mendukung pembentukan suatu teokrasi. Dalam pandangan Niẓām al-Mulk, Tuhan merupakan penguasa mutlak tidak hanya atas urusan politik, tetapi juga atas seluruh aspek kehidupan manusia. Namun demikian, Tuhan tudak menjalankan otoritas-Nya itu melalui apa yang disebut sebagai badan kependetaan (rabbäniyah). Ototritas itu,

\footnotetext{
42 Al-Mulk, The Book of Government, 12.

43 Ibid., 10.

${ }^{44}$ Ibid., 14.

${ }^{45}$ Lambton, "The Dilemma of Government", 57.

${ }^{46}$ Al-Mulk, The Book of Government, 9.
} 
menurut Nizām al-Mulk, dijalankan oleh sultan dan menterimenteri serta pejabat pemerintahan lainnya dalam suatu negara.

Niz̄ām al-Mulk tidak banyak membicarakan masalah kekhalifahan, dengan alasan bahwa lembaga itu tidak lagi memainkan peranan penting dan aktif dalam maysarakat politik. Lembaga tersebut telah direduksi menjadi sekadar simbol dan fungsinya telah menjadi sekedar sebuah mitos. Dalam kenyataan politik praktis, kedudukan sultan menjadi sangat penting, yang dalam pandangan Nizāam al-Mulk, memiliki hak-haknya sendiri dan memerintah sendiri, tidak sebagai penerima otoritas yang didelegasikan dari khalifah.

Menurut Nizāam al-Mulk, kesultanan merupakan instrumen Tuhan untuk memperbaiki kehidupan seperti telah dijelaskan di atas. Karena itu, sebagai penguasa, sultan dilengkapi dengan sifat dan karakter yang sempurna, seperti watak yang ramah, integritas yang kuat, kejantanan, keberanian, kecakapan, kecerdasan, keterampilan menggunakan senjata, apresiatif di bidang keseninan, rasa kasih sayang dan belas kasihan, kuat memegang janji, punya keyakinan agama yang benar, taat beribadah kepada Tuhan, hormat kepada otoritas agama, hormat kepada orang saleh, alim dan bijaksana, dermawan, peduli terhadap orang miskin, dan berpihak kepada mereka yang lemah an tertindas. ${ }^{47}$

Selain itu, sultan juga harus memperhatikan masalah peradaban dan kebudayaan. Misalnya, membangun saluran bawah tanah, saluran irigasi, jembatan penyeberangan, merehabilitasi area pertanian dan desa-desa, membangun benteng-benteng klasik dan bersejarah, membangun perumahan rakyat, penginapan dan madrasah bagi mereka yang menuntut ilmu pengetahuan. ${ }^{48}$ Untuk melaksanakan amanat Tuhan dan mengatasi urusan-urusan spiritual dan temporal, sultan melengkapi kecakapan individualnya itu dengan perlengkapan-perlengakapan teknis dan birokratis, yaitu dengan mengangkat menteri-menteri dan aparat pemerintahan negara, dengan memperhatikan tingkat kemampuan dan kecakapan melaksanakan tugas-tugas negara dan pemerintahan.

\footnotetext{
${ }^{47}$ Ibid., 11.

${ }^{48}$ Ibid., 10.
} 


\section{Sistem Pemerintahan dan Perlengkapannya}

Dalam suatu negara, terdapat pelbagai perangkat dan institusi yang masing-masing memiliki tugas dan fungisi berbeda. Perangkat-perangkat tersebut merupakan dan membentuk suatu kesatuan dan keutuhan yang integral dalam sebuah sistem pemerintahan negara.

\section{Wazī}

Wazīr, dalam pandangan Niz̄ām al-Mulk, merupakan tokoh utama (leading figure) dalam birokrasi. ${ }^{49}$ Adalah penting bagi seorang raja untuk mengetahui kualitas wazīr dan orang-orang yang dipercayainya untuk suatu jabatan politik, apakah mereka memenuhi tugas dan fungsi mereka secara tepat atau tidak. Sebab, baik dan buruknya negara akan sangat tergantung kepada mereka. Nizāam al-Mulk menyatakan:

Apabila wazìr itu mempunyai karakter yang baik dan putusan yang benar, maka kerajaan akan makmur, tentara dan rakyat akan puas dan senang, damai, tercukupi, sedangkan raja akan bebas dari kegelisahan. Tapi, jika wazīr itu buruk, maka kejahatan akan mengancam kerajaan, raja terus menerus merasa kebingungan dan kesukaran serta daerah-daerah dalam keadaan kacau balau. ${ }^{50}$

Nizām al-Mulk tidak menjelaskan secara detail mengenai kantor-kantor (diwwàn) yang berada di bawah koordinasinya, karena secara praktis ia berhasil mengendalikannya dengan baik. Ia menyebutkan bahwa wazir yang baik dengan sendirinya akan mempertinggi popularitas (kemasyhuran) rajanya. Demikian pula raja yang besar, terkenal, dan mencapai tingkat kajayaan yang tinggi adalah raja yang memiliki wažir yang baik dan cakap. Bahkan lebih dari itu, seorang wazir harus memiliki keyakinan agama yang benar dan harus diutamakan yang bermadzhab Shāfí̄i atau Hanafì. Ia juga harus efisien, cerdas, lihai, cerdik, dan cakap menulis serta setia (loyal) kepada rajanya. ${ }^{51}$

Wazir merupakan kepala dari seluruh pegawai atau pejabat dalam negara, sekaligus sebagai figur teladan. Jika wazir itu korup dan tidak adil, maka semua pejabat akan mengikutinya. Nizāam alMulk berpendapat bahwa seorang pejabat bisa saja sangat

\footnotetext{
${ }^{49}$ Lombton, "The Dilemma of Government", 61.

${ }^{50}$ Al-Mulk, The Book of Government, 23

${ }^{51}$ Ibid., 178.
} 
berpengalaman baik sebagai wazir, sekretaris, akuntan maupun pengusaha yang mungkin tidak ada bendingannya di dunia, tetapi bila ia seorang Yahudi, Kristen atau Zoroater, ia akan cenderung memandang rendah dan menghina orang-orang Muslim, dan bahkan akan menindas mereka secara kejam atas dalih pajak dan tanggungan keuangan. ${ }^{52}$ Maka jika orang Muslim ditindas oleh orang kafir dan mengeluhkan mereka, maka pejabat yang kafir itu harus dipecat dan dihukum.

Nizām al-Mulk menganjurkan agar seorang Muslim tidak memperhatikan dan terpengaruh oleh ucapan bahwa tidak ada pejabat di dunia ini yang dapat menandingi kecakapan orang nonMuslim; atau mungkin mereka mengatakan bahwa apabila pejabat itu dipecat dari kantornya, tugas-tugas akan mengalami kesulitan dan tidak seorang pun mampu menggantikan posisinya. Nizāàm alMulk menegaskan bahwa ucapan tersebut adalah kebohongan besar, dan karena itu tidak perlu diperhatikan. Sangat mutlak bagi raja untuk menggantinya dengan orang lain yang lebih baik, seperti yang pernah dilakukan oleh Khalifah 'Umar b. al-Khattāb terhadap seorang Yahudi. ${ }^{53}$

\section{Qādì}

Penentuan pejabat negara yang lain, termasuk qā $\bar{c}$ (hakim) adalah hak prerogatif raja (sultan). Qàd̄ memiliki fungsi yang sangat penting sebagai jembatan antara institusi agama dan isntitusi politik, antara sultan dan rakyatnya. Qäd̆ memainkan peranan penting dalam menjaga dan mentransmisikan tradisi peradaban Islam. ${ }^{54}$

Qà dì adalah wakil dan deputi sultan, ${ }^{55}$ dan ia ditunjuk langsung olehnya. Karena itu, sultan harus memberikan dukungan penuh kepadanya karena jabatan itu sangat penting dan meliputi semua urusan orang-orang Muslim. Qādì ini juga merupakan orang yang melaksanakan fungsi sultan di bidang hukum, lebih-lebih apabila sultan itu bukan orang Arab, misalnya Turki atau Persia, yang kurang mengerti bahasa Arab dan aturan-aturan hukum Islam. ${ }^{56}$

\footnotetext{
52 Ibid., 175.

53 Ibid.

54 Al-Mulk, The Book of Government, 43; Lambton, "The Dilemma of Government", 60 .

55 Ibid., 46.

${ }^{56}$ Ibid.
} 
Lapangan hukum ini juga mempunyai fungsi dan peranan politik, bahkan mencakup dimensi kebudayaan Islam yang luas.

Meskipun demikian, qā $\bar{\imath} \grave{\imath}$ haruslah bertindak adil, dan jika ia mengambil suatu keputusan dan menetapkan hukum secara berubah-ubah atau atas dasar kebencian dan rasa dendam, maka $q \bar{a} d_{\grave{l}}$ yang lain harus memberitahu sultan tentang putusan yang salah itu dan qā dì tersebut harus dipecat dan dihukum. ${ }^{57}$ Seluruh pejabat dan aparat pemerintah mempunyai kewajiban mendukung dan memperkuat posisi qădì dan menegakkan wibawa pengadilan. Jika ada seseorang yang membuat pernyataan maaf dan lalai untuk hadir di pengadilan, betapa pun mulianya orang itu, ia harus tetap dipaksa untuk menghadiri persidangan di pengadilan.

Nizām al-Mulk dalam masalah ini mensinyalir bahwa pada masa sahabat, keadilan diselenggarakan oleh mereka sendiri, tidak didelegasikan kepada orang lain. Karena itu, tidak ada kesempatan bagi munculnya ketidakadilan atau menghindar dari hukum. Apabila suatu bangsa atau negara dapat menerapkan persamaan dalam hukum, menegakkan keadilan dan berjuang demi keadlian, maka negara itu akan mampu bertahan dari generasi ke generasi selanjutnya. ${ }^{58}$ Menurut Nizāam al-Mulk, putusan yang benar dan adil adalah lebih baik bagi raja dari pada tentara yang sangat kuat sekalipun. $^{59}$

\section{Pegawai Pajak (Tax Collector)}

Perangkat negara yang lain yang memainkan peranan penting dalam pemerintahan adalah pegawai pengumpul pajak (tax collector). Pegawai pajak yang ditempatkan di wilayah keuangan terentu harus memperlakukan rakyat yang patuh secara baik dan sopan. Pemungutan pajak itu sendiri harus didasarkan pada jumlah yang sudah ditetapkan dan dilakukan pada waktu-waktu yang sudah ditentukan. Sebab, jika hal ini tidak dilaksanakan oleh pegawai pajak itu, maka rakyat akan terganggu dan mereka harus menjual separuh hasil panennya, serta dihadapkan pada kebutuhankebutuhan yang mendesak, hingga pada akhirnya mereka terpaksa harus bermigrasi (pindah). ${ }^{60}$ Kalau rakyat berada dalam kesulitan seperti ini, mereka harus diberi pinjaman untuk meringankan

\footnotetext{
${ }^{57}$ Ibid., 44.

${ }^{58}$ Ibid.

${ }^{59} \mathrm{Ibid}$

${ }^{60}$ Ibid., 223.
} 
beban, dan menjaga mereka agar tetap dapat hidup dan tidak terlempar ke pengasingan.

Nizāam al-Mulk mengemukakan bahwa pada suatu saat selama tujuh tahun terjadi masa paceklik. Tetapi berkat kebaikan dan keadilan raja, ia menyuruh pegawai pajak (keuangan) untuk menjual semua persediaan padi yang ada dan memberikan hasilnya secara sosial kepada rakyat. Semua orang miskin di negara itu ditolong oleh bagian keuangan pusat dan lokal, sehingga tidak terdapat seorang pun yang mati kelaparan selama masa tersebut. ${ }^{61} \mathrm{Hal}$ ini dengan sendirinya merupakan suatu keteladanan dalam melindungi kesejahteraan dan kelangsungan hidup semua warga negara/ masyarakat.

Namun demikian, terhadap pegawai pajak itu harus dilakukan pemeriksaan, apakah mereka menjalankan tugasnya dengan baik dan benar atau tidak. Jika mereka bertugas dengan baik, maka kondisi keuangan negara dan rakyat akan dapat dikendalikan. Tetapi jika mereka mengambil pajak lebih dari jumlah yang sudah ditentukan, maka kelebihan itu harus dikembalikan lagi kepada rakyat. Sedangkan sisa kekayaan pegawai tersebut harus disita dan diserahkan kepada bagian keuangan. Pegawai itu harus diganti dan pegawai lain harus menjadikan kasus itu sebagai peringatan untuk tidak berlaku korup dan opresif. ${ }^{62}$

\section{Agen Intelijen dan Mata-mata}

Dalam pada itu, untuk mengetahui setiap perkembangan yang terjadi di seluruh penjuru negeri, raja harus menempatkan agen intelejen di pos-pos penting. Sebab, jika raja tidak mengerti sama sekali kondisi sosial dan ekonomi masyarakat, maka rakyat akan menuduhnya sebagai sembrono, malas, dan tiran.

Melalui agen-agen itulah raja akan memahami peristiwa pencurian, penindasan dan pemerasan yang dilakukan oleh orang atau kelompok tertentu dalam masyarakat. Tugas mereka ialah megecek aktivitas para pemeras, sehingga rakyat dapat menikmati keamanan dan keadilan dalam urusan perdagangan, pertanian, dan lain sebagainya. Karena tugasnya yang demikian itu, maka pekerjaan ini sebaiknya diserahkan kepada orang-orang yang dapat dipercaya secara sempurna dan sama sekali tidak dicurigai serta tidak mempunyai kepentingan pribadi (self-interest). Mereka

\footnotetext{
${ }^{61} \mathrm{Ibid}$
}

62 Ibid. 
bertanggung jawab langsung kepada raja dan menerima gaji secara teratur setiap bulan dari bagian keuangan. Melalui cara seperti ini, raja akan memberikan perintah, hukuman, hadiah, dan penghargaan berdasarkan informasi yang secara obyektif diterimanya dari para anggota intelijen. ${ }^{63}$ Dengan demikian, penggunaan agen intelijen itu memberikan sumbangan yang sangat berarti bagi tegaknya keadilan; adanya kewaspadaan dan kebijaksanaan raja bagi kesejahteraan dan kemakmuran negara.

Selain agen intelijen, para raja juga harus menyebarkan matamata (spies) sampai perbatasan negara dengan menyamar sebagai pedagang, pelancong, sufi, penjaja obat atau pemngemis, untuk kemudian membawa pulang informasi mengenai apa saja yang ia dengar dan saksikan. Dengan demikian, tidak akan terdapat sesuatu masalah yang tersembunyi dan bila terjadi sesuatu hal akan dapat segera diatasi dan diperbaiki. ${ }^{64}$ Adalah biasa terjadi bahwa gubernur atau komandan merencanakan suatu pemberontakan dan perlawanan serta merencakana usaha kudeta terhadap raja. Tetapi, karena ada mata-mata yang disebar, gerakan mereka segera diketahui dan dengan segera pula rencana pemberontakan dapat digagalkan, bahkan raja dapat memukul mundur dan menghancurkan gerakan subversif itu. ${ }^{65}$ Demikian pula halnya dengan kurir yang ditempatkan di sepanjang jalan-jalan penting untuk memonitor dan memantau kondisi masyarakat, sehingga segala sesuatu yang terjadi selama 24 jam dan dalam radius 3,5 mil dapat diketahui. ${ }^{66}$

\section{Boon-Companion}

Nizāam al-Mulk menunjukkan kepada sultan bahwa seorang raja tidak akan dapat bertindak tanpa adanya sahabat dekat (booncompanion) yang cocok, yang dengannya dapat menikmati suasana kebebasan yang sempurna dan suasana keakraban. ${ }^{67}$

Menurut Nizām al-Mulk, banyak sekali manfaat memiliki booncompanion itu; pertama, mereka akan menemani raja setiap waktu; kedua, selama mereka bersama raja dan kalau timbul suatu bahaya mereka tidak akan ragu-ragu untuk melindungi raja dari bahaya itu

\footnotetext{
${ }^{63}$ Ibid., 66.

${ }^{64}$ Ibid., 78.

65 Ibid.

${ }^{66}$ Ibid., 91.

${ }^{67}$ Ibid., 92.
} 
dengan kekuatan fisik mereka (sebgai body-guard); ketiga, raja dapat menemukakan pelbagai permasalahan negara lainnya; dan keempat, semua bentuk dan macam informasi dapat ia peroleh dari mereka, karena melalui kebebasan mereka dapat dilaporkan semua masalah yang memuaskan dan yang tidak memuaskan. ${ }^{68}$ Karena itu, mereka hendaknya dipilih dari keluarga yang baik, punya kepandaian dan roman muka yang riang. Mereka harus baik agamanya, dapat menjaga rahasia-rahasia dan berpenampilan menarik. Mereka mesti humoris, memiliki hikayat-hikayat asing dan dapat menceritakannya kepada raja dengan lancar dan menyenangkan. ${ }^{69}$

Nizām al-Mulk menceritakan bahwa raja-raja tertentu ada yang memiliki dokter (physician) pribadi, atau juga astrolog (peramal). Dokter mengawasi kesehatan raja, sedangkan astrolog memberitahukan saat yang terbaik bagi raja untuk bertindak dan bersikap. Namun, beberapa raja tidak menganggap mereka sebagai penting, karena bisa jadi mereka malah menjerumuskan posisi raja dan menjadi penghalang serta mempersempit kebebasan raja.

6. Musyawarah

Lebih lanjut Nizām al-Mulk menasihati raja, bahwa di dalam urusan-urusan yang bersifat rekreatif, raja harus meminta pertimbangan kepada pendampingnya, boon-companion, sebab mereka ditunjuk untuk tugas itu. Namun, dalam urusan-urusan kenegaraan seperti militer, pemerintahan dan lainnya raja harus berkonsultasi dan bermusyawarah dengan wazīr beserta pejabat negara lainnya yang lebih berpengalaman, sebab mereka memiliki keahlian dalam masalah tersebut. ${ }^{70} \mathrm{Di}$ sinilah letak penting musyawarah dalam pemikiran Nizāàm al-Mulk.

Dalam pandangannya, melaksanakan musyawarah dalam pelbagai masalah merupakan tanda bahwa orang itu mempunyai pertimbagnan yang sehat dan obyektif, kecerdasan yang tajam dan pandangan jauh ke masa depan. ${ }^{71}$ Setiap orang mempunyai pengetahuan dalam masalah teretentu, tetapi bisa jadi tidak mengerti masalah yang lain. Itulah sebabnya mengapa seseorang harus minta pertimbangan kepada orang lain yang bijaksana, berpengalaman dan yang memiliki intelektualitas cemerlang. Niẓām al-Mulk

\footnotetext{
${ }^{68}$ Ibid., 93.

${ }^{69}$ Ibid.

${ }^{70}$ Ibid.

${ }^{71}$ Ibid., 95.
} 
menyatakan: "The counsel of one man is like the strength of one man, and the counsel of ten persons is as the strength of ten men" "72 (Pertimbangan dari satu orang laksana dukungan kekuatan satu orang, dan pertimbangan dari sepuluh orang berarti dukungan kekuatan sepuluh orang).

Nizāàm al-Mulk juga menytakan bahwa meskipun Nabi Muhammad merupakan manusia yang bijaksana dan sempurna, namun Allah tetap menyuruhnya untuk bermusyawarah dengan umatnya dalam pelbagai urusan. Karena itu, jika raja akan melakukan suatu pekerjaan atau menghadapi masalah yang penting, ia harus berembuk dan mendiskusikan masalah itu dengan orang yang bijaksana, mendengarkan satu sama lain, untuk melahirkan suatu kesepakatan bersama sebagai keputusan yang harus ditaati. ${ }^{73}$ Dalam pandangan Nizām al-Mulk, orang yang tidak mau bermusyawarah dalam urusan bersama akan memperlihatkan putusan yang lemah, dan tepatlah bila dikatakan "no task can be accomplished without men of the proper skill; no more can any enterprise succeed without deliberation". ${ }^{74}$

Demikian pula, dalam menyelesaikan persoalan-persoalan kenegaraan yang kompleks dan menyangkut kehidupan orang banyak, musyawarah menjadi sangat mutlak sehingga dalam komunitas tersebut berkembang suasana demokratis, dan penguasa tidak bertindak represif dan otoritarian. Sebab, sikap atau tindakan represif itu merupakan salah satu faktor yang dapat mengakibatkan runtuhnya kekuasaan dan kekuatan. Dalam pandangan Nizām alMulk, musyawarah dan penegakan demokrasi merupakan implementasi nilai-nilai moral dan etik Islam dalam kehidupan masyarakat.

7. Militer

Selain perangkat-perangkat di atas, kekuatan (pasukan) militer merupakan alat negara yang sangat penting. ${ }^{75}$ Nizāam al-Mulk menyadari bahwa Saljuk, sebagaimana dinasti lain, sangat bergantung kepada orang Turki, dan ia menyebut adanya hubungan khusus antara mereka dengan kerajaan. Ia menganjurkan untuk mempekerjakan mereka di istana dan dalam dinas ketentaraan,

72 Ibid.

73 Ibid.

${ }^{74}$ Ibid., 96.

75 Ibid., 102-103. 
tetapi ini tidak berarti bahwa ia menerima mereka sebagai faktor yang memainkan peranan penting dalam negara.

Bagaimanapun, menurut Nizāam al-Mulk, kekuatan militer sangat penting dan dibutuhkan dalam sebuah negara, meskipun ia tidak sependapat jika mereka diberi kesempatan untuk menguasai negara. Nizām al-Mulk berpendapat bahwa pasukan tentara harus tidak hanya terdiri dari satu suku saja, sebab hal itu akan menyebabkan timbulnya bahaya dan kekacauan. Pasukan yang hanya terdiri dari satu suku tidak akan memiliki semangat, dan mereka cenderung tidak tertib (disiplin).

Sangat penting untuk menyusun pasukan yang menghimpun berbagai ras atau suku, seperti Khurasan, Daylamī dan bahkan Georgia. Hal serupa pernah dilakukan Sultan Mahmūd Ghaznah yang berhasil membangun kekuatan militer yang terdiri dari orang Turki, Khurasan, Arab, dan Hindu. Dalam suatu ekspedisi meliter, pasukan itu mempunyai tugas menjaga pos-pos tertentu di dalam dan di luar kota. Setiap ras dan suku yang tergabung dalam pasukan akan menunjukkan kehebatan mereka masing-masing, sehingga "esprit de corp" mereka akan tumbuh dan akhirnya dapat memenangkan pertempuran dan peperangan. ${ }^{76}$

\section{Penutup}

Dari pembahasan terdahulu, beberapa catatan kesimpulan dapat disebutkan sebagai berikut: pertama, Nizām al-Mulk tercatat berhasil mencapai prestasi yang cemerlang sebagai seorang wazir, negarawan (politisi). Ia tidak hanya terlibat dalam masalah-masalah yang praktis, tetapi juga dalam perumusan kebijakan politik dan pemikiran konseptual mengenai pemerintahan. Pada masanya, kesatuan dunia Islam dapat diwujudkan dengan mempertahankan kehkhalifahan sebagai simbolnya dan dengan mengefektifkan keberadaan kesultanan. Kedua, pandangan politik yang tertuang dalam Siyäsat-näma mencerminkan komitmennya yang kuat terhadap ajaran Islam dengan tetap memperhatikan aspirasi sosial dan realitas kultural yang berkembang di lingkungannya, serta warisan dan tradisi politik Persia kuno. Cita-citanya mewujudkan keadilan sosial, ekonomi, dan politik sangat kuat sebagaimana tampak pada pernyataannya mengenai agama dan keadilan sebagai

${ }^{76}$ Ibid., 104. 
dasar negara; bahwa negara hanya bisa bertahan dengan keadilan, meskipun tanpa agama.

\section{Daftar Rujukan}

Bowen, Harold. "Nizāām al-Mulk", The Encyclopaedia of Islam, New Edition, Vol. 8.

Brockleman, Karl. Tārikh al-Shu'üh al-Islämìyah. Beirut: Dār a-'Ilm, 1974.

Browne, E.G. A Literary History of Persia, Vol. 2. Cambridge: Cambridge University Press, 1964.

Bulliet, R.W. "The Political-Religious History of Nishapur in The Eleventh Century", dalam D.H. Richards (ed.), Islamic Civilization 950-1150. London: Cassirer, 1973.

Farrā' (al), Abū Ya'lā. al-Aḥkēm al-Sultānīyah. Beirut: Dār al-Fikr, 1994.

Hiilmī, Aḥmad Kamāl al-Dīn. al-Salājiqah fì al-Tārikeh wa al-Haḍarah. Kuwait: Dār al-Buhūth al-'Ilmīyah, t.th.

Hitti, Phillip K. History of the Arabs from the Earliest Times to the Present. London: Macmillan, 1967.

Hodgson, Marshal G.S. The Venture of Islam II. Chicago: The University of Chicago Press, 1974.

Ibn al-Athīr. al-Kämil fì al-Tärikh, Vol. 10. Beirut: t.tp, 1966.

Lambton, A.K.S. "The Dilemma of Government in Islamic Persia:

The Siyasat Nama of Nizam al-Mulk," Iran: Journal of the British Institute of Persian Studies, Vol. 22, 1984.

Maḥmūd, Ḥasan Aḥmad dan Aḥmad Ibrāhīm al-Sharīf. al-'Álam alIslàm fì al-'Ashr al-'Abbāsì. Kairo: Dār al-Fikr al-'Arabī, 1977.

Mawardī (al), Abū al-Ḥasan 'Alī b. Muḥammad b. Habib. al-Ạ̣kām al-Sultāniyah wa al-Wilāyāt al-Dinìyah. Beirut: Dār al-Fikr, 1960.

Mulk (al), Nizām. The Book of Government, terj. Hubert Darke. London: Routledge and Kegan Paul, 1960.

Rizvi, S. Rizwan Ali. Nizam al-Mulk Tusi: His Contribution to Statecraft, Political Theory and the Art of Government. Lahore: SH Muhammad Ashraf, 1978.

----. "Niz ām al-Mulk Tūsī: Not A Politician but A Statesman", Hamdard Islamicus, Vol. 3, No. 4, 1980.

Shalabī, Aḥmad. Mawsū'at at-Tärīkh al-Islāmì wa al-Hādārah alIslämìyah. Kairo: Maktabah al-Nahḍah al-Mișrīyah, 1978. 
Sherwani, Haroon Khan. Studies in Muslim Political Thought and Administration, terj. M. Arief Lubis. Jakarta: Tintamas, 1964.

Sou'yb, Jousouf. Sejarah Daulat Abbasiyyah III. Jakarta: Bulan Bintang, 1978.

Subkī (al), Tāj al-Dīn. Țabaqat al-Shäfíìyah al-Kubrā. Kairo: alHalabī, 1966.

Watt, W. Montgomery. Pemikiran Teologi dan Filsafat Islam, terj. Umar Basalim. Jakarta: P3M, 1987. 